\title{
Dogmatikk som samtidsteologi
}

\author{
En kritisk videreutvikling av N.H. Gregersens program
}

\author{
Ph.d.- stipendiat, M.Th., Asle Eikrem
}

\begin{abstract}
The article develops a sketch for a critical systematic reconstruction of Niels Henrik Gregersen's framework for "Dogmatics as Contemporary Theology". Three main issues are taken up for discussion. First, the relation between semantics and pragmatics is investigated. Secondly, the important theoretical procedure of "explication" is clarified in accordance with the three orders of systematic theological procedures found in Gregersen's framework. Through this discussion a third, and final, problem announces itself: how are we to determine the thematic fields of each order of systematic theological discourse: theology1, 2 , and 3 ? From the soil tossed and turned by this discussion, and contrary to strong trends in many so-called post-metaphysical ways of thinking, reasons are given why an explicated depth-metaphysical framework is necessary for clarifying the procedures of "Dogmatics as Contemporary Theology".
\end{abstract}

Key words: Semantics - pragmatics - explication - Gregersen - Puntel metaphysics - universalism - coherentism.

\section{Introduksjon}

Niels Henrik Gregersen skisserer et interessant rammeverk for teologisk dogmatikk i sin artikkel med tittelen "Dogmatik som samtidsteologi” i DTT, 71, 2008 (s. 290-310). I det følgende ønsker jeg å presentere og rekonstruere hans bidrag til forståelsen av dogmatikk som systematisk teologisk virksomhet. Rekonstruksjon betyr her at jeg, med utgangspunkt i Gregersens eget begrepsmessige og metodiske rammeverk, vil forsøke kritisk å presisere hans ansatser. Mitt bidrag til denne debatten vil være orientert rundt tre forhold. For det første vil jeg nærmere bestemme hvordan vi bør forstå forholdet mellom semantikk og pragmatikk i Gregersens modell. For det andre vil jeg presisere Gregersens begrep "eksplikasjon", og relatere det til måten han fremstiller dogmatikkens komparative dimensjon på. For det 
tredje vil jeg forsøke å presisere de tematiske feltene for de ulike arbeidsmåtene i dogmatikk, slik Gregersen skisserer disse.

\section{Grunntrekkene i Gregersens ansats}

Gregersen definerer dogmatikk som "...studiet av den nutidige kristendoms store betydningsuniverser (semantikker) med henblik på at udarbejde en sammenhengende kristendomstolkning, der på forskellige måde kan gøre kristendommen gældende som en mulig livstydning og livsform (pragmatik)". ${ }^{1}$ Denne formuleringen introduserer en rekke betydningstunge begreper som krever betydelig grad av presisjon for å kunne gjøres operasjonelle på en teoretisk forsvarlig måte innenfor dogmatisk arbeid. Gregersen utfolder denne definisjonen som en modell for dogmatisk teologi med tre dimensjoner: ${ }^{2}$

1. Første ordens teologi: eksplikasjon av ulike kristne semantikker slik de opptrer i samtidige praksisformer (sakramenter, bønn, bekjennelse, lovprisning, prekener etc.). ${ }^{3}$

2. Andre ordens teologi: normativ presentasjon av den indre sammenheng (koherens) i et størst mulig omfang av kristne semantikker.

3. Tredje ordens teologi: kritisk-komparativ presentasjon av kristne semantikker i relasjon til andre religiøse og ikke-religiøse semantikker. Ekstern koherens er her kriterium for hvilken semantikk som er den beste.

Som helhet fremstår Gregersens forståelse av dogmatikk som et samtidsorientert vitenskapelig kulturstudium. Den tar utgangspunkt i de kulturelle fortolkningsmønstre som allerede eksisterer i samtidige kristne praksissammenhenger, og har som siktemål systematisk å presentere disse slik at de fremstår som beste mulige (les: mest koheren-

1. Niels Henrik Gregersen, "Dogmatik som samtidsteologi", Dansk Teologisk Tidsskrift 71 (2008), 291f, jf. 302.

2. Ibid., 307ff.

3. For Gregersen betyr ikke dette at dogmehistorie eller studier av tradisjonelle teologier (eks. Augustin, Luther, Calvin) blir uinteressant innenfor dogmatisk arbeid. I kraft av å være fiksert i skrifter er tradisjonelle teologier en del av samtidsteologiens ressurstilfang. Ibid.,295. Sml. Niels Henrik Gregersen, "How to Cope with Pluralism in Dogmatics. A Proposal", Studia Theologica 44, no. 2 (1990), 134. 
te) allmenne kandidater for faktisk livsorientering. I mitt forsøk på å presisere og videreutvikle Gregersen ansatser vil jeg her stille tre nært relaterte spørsmål.

1. Hvordan skal vi mer presist forstå forholdet mellom pragmatikk og semantikk i det Gregersen kaller teologi 1?

2. Hva innebærer det mer presist å eksplisere i denne sammenheng, og hvordan kan eksplikasjon forstås i sammenheng med det komparative aspektet ved systematisk teologisk arbeid?

3. Hvordan bestemmer vi det tematiske feltet for henholdsvis teo$\operatorname{logi} 1,2$ og 3, og hvordan skal vi metodisk nærmere bestemme disse tre praksisene som sådan?

Hva dreier systematisk teologisk eksplikasjon seg om?

Det metodiske utgangspunktet for dogmatisk virksomhet av første orden kaller Gregersen "eksplikasjon". Gregersen forstår eksplikasjon som "tyk beskrivelse" av det kristne sprogunivers i funktion, sådan det forstås ud fra et brugerperspektiv." 4 Det første trinnet i dogmatisk arbeid består altså i, på en helt bestemt måte, å beskrive "den faktisk levede kristendom i nutiden" slik kristne mennesker selv forstår denne. ${ }^{5}$ Disse formuleringene vekker innledningsvis spørsmålet om det første trinnet i dogmatiske fremstillinger handler om å gjøre seg kjent med kristne menneskers selvforståelse slik det er artikulert fra et førstepersonsperspektiv ("Dette gjør/sier jeg...”), eller om det handler om en teoretisk fremstilling fra et tredjepersonsperspektiv ("Det forholder seg slik at kristne mennesker sier/gjør dette"). ${ }^{6}$ Svaret på dette spørsmålet må med nødvendighet være det siste. Var ikke dette tilfellet, ville dogmatikk i beste fall vært redusert til religionssosiologi, og ikke ha status som systematisk (evt. teoretisk) teologisk virksomhet. For å nærme oss et svar på spørsmålet om hvordan vi skal forstå hva systematisk teologisk eksplikasjon faktisk går ut på, må vi klargjøre hva det er som skal ekspliseres.

Hva betyr det at dogmatisk arbeid begynner med å eksplisere kristendommens semantikker? Kristendommens "semantikker" forstår

4. Gregersen (2008),308, jf. 292, 303.

5. Ibid.,292, jf. 303.

6. Lorenz B. Puntel, Sein und Gott : Ein systematischer Ansatz in Auseinandersetzung mit M. Heidegger, E. Levinas und J.-L. Marion, Philosophische Untersuchungen, (Tübingen: Mohr Siebeck 2010), 185-90. 
Gregersen ikke eksklusivt som bibeltekstenes betydningsunivers, men som de (bl.a. mer eller mindre, og på ulike måter, bibelsk orienterte) meningskonstellasjoner som kommer til uttrykk i samtidens ulike kristne sammenhenger. ${ }^{7}$ Betyr dette at dogmatisk arbeid av første orden dreier seg om å eksplisere hva mennesker gjør, hva de sier, eller hva de sier i kraft av det de gjør? Vi må m.a.o. klargjøre om dogmatisk arbeid av første orden handler om å eksplisere semantiske eller pragmatiske strukturer? M.a.o. handler teologi av forste orden om å eksplisere hva kristne mennesker gjør, eller handler den om å eksplisere hva kristne mennesker uttrykker når de gjør noe? Dette spørsmålet blir ikke tydelig besvart i Gregersens fremstilling, hvor det kun presenteres generelle beskrivelser av hvordan dette forholdet skal forstås. Han slår fast at studiet av kristendommens semantikker i utgangspunktet også er studiet av dens pragmatikker, og henviser som sagt til Clifford Geertzs anvendelse av Gilberty Ryles filosofiske begrep "tyk beskrivelse" for en utdyping av hvordan slike studier utfolder seg. Hos Geertz blir dette begrepet brukt for å beskrive måten man fortolker det som blir sagt i og gjennom komplekse kulturelle handlingsmønstre. Geertz skriver:

What the ethnographer is in fact faced with [...] is a multiplicity of complex conceptual structures, many of them superimposed upon or knotted into one another, which are at once strange, irregular, and inexplicit, and which he must somehow contrive first to grasp and then to render [...] The thing to ask is what their import is: what it is [...] that, in their occurances and through their agency, is getting said. ${ }^{8}$

Menneskelig praksis er altså, ifg. Geertz, ikke ren atferd, men semantisk (evt., semiotisk) strukturert, hvilket vil si at den er hva den er i kraft av å si oss noe - den er meningsberende. ${ }^{9}$ Det semantiske og det pragmatiske er her to dimensjoner ved en og samme struktur: menneskelig væren-i-verden.

Det er imidlertid ikke bare enheten mellom disse dimensjonene som kan ekspliseres. Vi kan også forsøke å eksplisere forholdet mellom disse dimensjonene som sådan. Eksplikasjon handler nemlig om stadig å artikulere mer raffinerte strukturelle nyanser. ${ }^{10}$ Hvordan kan

7. Gregersen (2008), 292.

8. Clifford Geertz, The Interpretation of Cultures (New York: Basic Books 1973), 10.

9. "Ren atferd" er her brukt synonymt med det Geertz kaller "a body of uninterpreted data" som er selve den begrepsmessige motsatsen til tykke beskrivelser. Denne ufortolkede databasen består nemlig, ifg. Geertz, av "radically thinned descriptions". Ibid., 16.

10. Jf. Lorenz B. Puntel and Alan White, Structure and Being : A Theoretical Framework for a Systematic Philosophy (University Park, Pa.: Pennsylvania State Uni- 
vi da mer bestemt forstå forholdet mellom det pragmatiske og det semantiske? Svaret på dette spørsmålet har betydning for hvordan vi skal forstå det deskriptive arbeidet i dogmatisk samtidsteologi på en mer presis måte enn det Gregersens tekst muliggjør.

Innholdet i de meningsbærende handlinger som utgjør "kristne betydningsuniverser" bestemmes på ulike måter. ${ }^{11}$ Eksplikasjon handler om narmere a bestemme spräket $i$ relasjon til dets pragmatiske, semantiske og ontologiske dimensjon. For det første blir meningsbærende handlinger bestemt kontekstuelt av forhold i menneskers livsverden. Så fremt mennesker forstår hverandre når de kommuniserer ved hjelp av kristne ord, uttrykk og andre meningsbærende handlinger, er disse livsverdensmessig fullt bestemt. Oppstår det usikkerhet om hvilke handlinger som utføres, krever fortsatt kommunikasjon at man foretar en nærmere bestemmelse av de meningsbærende handlingene (språklige så vel som ikke-språklige) som utføres i en kommunikativ situasjon. Slike oppklaringer kan utføres fra et brukerperspektiv, eller det kan inngå som en del av dogmatikkens eksplikasjonsarbeid. I dogmatisk arbeid vil vi søke å gjenopprette det vi kan kalle en pragmatisk forståelse av det som gjøres i kristne sammenhenger. Dogmatikeren kan da utføre det jeg (med Puntel) vil kalle en lingvistisk-pragmatisk bestemmelse (evt. lingvistisk-pragmatisk eksplikasjon) av det kristne mennesker gjør når de lever ut sin tro. Eksempelvis kan man si til den/dem man snakker med at det vi nå gjør er ikke å be, men å utføre en blasfemi. Lingvistisk-pragmatisk å bestemme kristne handlinger, eller handlingsmønstre, handler ikke nødvendigvis om å fremstille dem som mest mulig koherente. Det første trinnet i dogmatikk som samtidsteologi handler om å forstå hva kristne mennesker gjør, uavhengig av om innholdet i disse handlingene for teologen fremstår som koherent eller ikke. Selve fremstillingen av handlingene må imidlertid være koherent dersom den skal kunne kalles en vitenskapelig (teoretisk) fremstilling. Da er vi imidlertid ikke lenger opptatt av språkbrukerens selvforståelse, men av evt. å oppklare teoretiske uklarheter $\mathrm{i}$ en fremstilling av kristne handlingsmønstre. En teologisk fremstilling av hva kristne mennesker gjør, er m.a.o. en teoretisk presentasjon av kristne meningsbærende handlinger, der man forsøker optimalt å bestemme den pragmatiske dimensjonen ved de semantis-

versity Press, 2008), 405-11, og Lorenz B. Puntel, Grundlagen einer Theorie der Wahrheit, Grundlagen der Kommunikation und Kognition = Foundations of Communication and Cognition (Berlin ; New York: W. de Gruyter, 1990), 88ff.

11. Jeg følger her L.B. Puntels modell for pragmatisk, semantisk og ontologisk bestemmelse. Se Puntel (1990), 88ff., Puntel and White (2008), 150ff. og Puntel (2010), 172ff. 
ke strukturer som utgjør "kristendommens store betydningsuniverser".

For optimalt å forstå hva kristne mennesker gjør, må en rekke språkeksterne (asemantiske) faktorer tas med i betraktning (faktorer som bestemmer det språklige subjektets relasjon til andre subjekter, situasjon, kontekst, osv.). Slike pragmatiske oppklaringer består derfor ikke utelukkende i å eksplisere rene semantiske forhold. Men det er heller ikke slik at semantiske forhold kan ekspliseres optimalt ved fullt å bestemme semantikkens pragmatiske dimensjon. Selv om den pragmatiske dimensjonen ved språket ikke kan løsrives fra den semantiske, er ikke disse sammenfallende. En kristen språkhandling, som eksempelvis liturgisk bønn innenfor rammene av en gudstjeneste, er ikke identisk med innholdet bønnen uttrykker. A eksplisere hva kristne mennesker gjør $i$ en bestemt sammenheng, er ikke det samme som a eksplisere hva disse menneskene uttrykker når de gjør noe. Videre: mens pragmatisk eksplikasjon forutsetter at de uttrykkene man bruker for å oppklare pragmatiske forhold er semantisk bestemt (vi må f.eks. ha semantiske ressurser tilgjengelig for å forstå en pragmatisk eksplikasjon), forutsetter ikke semantisk eksplikasjon at noe faktisk uttrykkes, men at noe kan uttrykkes, dvs. at noe kan artikuleres som noe. Selv om de er gjensidig relatert, er ikke kristne semantikker reduserbare til kristne pragmatikker. Kristne mennesker handler som om det de gjør faktisk uttrykker noe, dvs. er informativt (semantisk bestemt), og som om det de sier faktisk forholder seg slik (dvs. at det er ontologisk fullt bestemt). Slik sett er de språkpragmatiske oppklaringer som utføres i det arbeid som konstituerer den teoretiske praksis vi kaller teologi 1 , semantisk og ontologisk betinget. Dogmatikkens arbeid kan derfor ikke begrense seg til optimalt å bestemme (evt. eksplisere) hva kristne mennesker faktisk gjør. Den består også i fullt å bestemme hva kristne mennesker uttrykker når de gjør noe. Skulle det siste spørsmålet oppta oss, beveger vi oss fra en teoretisk lingvistisk-pragmatisk eksplikasjon til en teoretisk semantisk-ontologisk eksplikasjon. ${ }^{12}$ En eksplikasjon av sistnevnte type er rent semantisk, dvs. ingen spräkeksterne forhold tas med $i$ betraktning. Vi er da kun opptatt av å eksplisere indrespråklige sammenhenger. Som vi skal se kan begrepet eksplikasjon videreføres som metodisk nøkkelbegrep i så vel teologi av første, andre som tredje orden.

Så langt har mitt forslag vært å rekonstruere teologi av første orden som teoretisk lingvistisk-pragmatisk eksplikasjon av "det kristne sprog i funktion". Siktemålet for teologi av første orden er derfor å avklare pragmatiske faktorer som er medbestemmende for innholdet 
i kristen språkbruk slik at den pragmatiske dimensjonen ved slik språkbruk som helhet blir (teoretisk) fullt bestemt. Men hva betyr det at en slik presentasjon blir fullt bestemt?

\section{Eksplikasjon av første, andre og tredje orden}

Innledningsvis må et svar på dette spørsmålet bestå i å vise hvordan vi bestemmer det tematiske feltet for henholdsvis teologi 1, 2 og 3 (jf. tredje spørsmål ovenfor). Som definisjonen ovenfor viser, angir Gregersen dogmatikkens tema som kristne semantikker/pragmatikker. Valget av flertallsform er neppe tilfeldig. Spørsmålet som da melder seg, er hvordan dette arbeidet mer presist skal gjennomføres metodisk. Hvordan, og på hvilket grunnlag, avgrenser vi kristendommens "ulike" semantikker/pragmatikker fra hverandre, og hvordan, og på hvilket grunnlag, kan vi avgrense kristendommens semantikker/pragmatikker fra andre semantikker/pragmatikker? Liksom det er viktig å vite hvilke forhold som skal tas med i betraktning når man forsøker å utvikle en systematisk teologi, er det en forutsetning for kritisk vurdering av en dogmatisk fremstilling at det er klart hva som faller inn under dens tema og hva som ikke gjør det. Eksisterer det uklarheter om hva som faller inn under et teoretisk område, vil den systematiske fremstillingen være teoretisk underbestemt. ${ }^{13}$

Gregersen anerkjenner at kristne semantikker generelt sett ikke kan bestemmes ved å artikulere dens overhistoriske konstituerende essens, men er likevel noe tvetydig i måten han, inspirert av Pannenberg, skiller mellom dogmatikkens "egentligste genstand" (Guds selvåpenbaring slik den umiddelbart erfares) og teologiens "faktiske genstand" (konkrete tydninger av Guds selvåpenbaring slik den kommer til uttrykk i kristne språkpraksiser). ${ }^{14}$ Hvilken mening kan vi egentlig gi den førstnevnte gjenstand? Det må i så fall bestå i det forholdet at det som faktisk er uttrykt om Gud og det som kan uttrykkes om Gud, ikke sammenfaller. Dogmatikkens arbeid må derfor gå ut på stadig å artikulere flere dimensjoner ved Gud slik han faktisk forholder seg som uttrykkbar. ${ }^{15}$ Semantisk sett er imidlertid Gud kun tematiserbar som "faktisk gjenstand".

13. Puntel (1990), 90-98.

14. Gregersen (2008), 305. Sml. Gregersen (1990), 132. I sistnevnte artikkel kan han tolkes dithen at han bestemmer denne egentligste gjenstand som en apofatisk dimensjon ved Gud. Problemet er at denne apofatiske dimensjonen er per definisjon meningsløs (dvs. ikke språklig artikulerbar).

15. Jf.Puntel (2010), $189 f$. 
Dogmatikkens temakrets endrer seg dermed i takt med hvordan kristne semantikker endrer seg innenfor de samtidspraksiser de inngår i. Et godt eksempel på dette er etableringen, og utviklingen, av en mer "feministisk" orientert diskurs i mange kristne sammenhenger. Gregersen taler likevel ganske uproblematisk om "det kristne sprog" og "den levede kristendoms basale praksiser" som dogmatikkens tema, og angir historisk kontinuitet som det aspekt som knytter sammen kristen tradisjon slik at det utgjør et slags autentisitetskriterium som avgrenser disse størrelsene fra ikke-kristne språk og praksiser. ${ }^{16} \mathrm{Er}$ dette tilstrekkelig? Selv om det hefter betydelig uklarhet rundt det alternativet han selv antyder, støtter jeg Gregersen $\mathrm{i}$ hans ansatser til å avvise en essensialistisk bestemmelse av kristne semantikker/pragmatikker. Men hvordan kan vi gjøre dette enda klarere?

Dogmatikken bestemmer kristne semantikker/pragmatikker ved å eksplisere dem relasjonelt, og da ikke kun i lys av andre kristne semantikker/pragmatikker. Mens Gregersen mener hensynet til ikke-kristne semantikker/pragmatikker ikke er konstitutiv for teologi av første og annen orden, men derimot kun for teologi av tredje orden, mener jeg at ikke-kristne semantikker/pragmatikker også har relevans for arbeidet innenfor teologi av første orden. Hvordan kan dette la seg begrunne?

Wittgenstein beskrev menneskelig språk som et nettverk av familielike språklige praksiser, og den walisiske religionsfilosofen D.Z. Phillips anvendte Wittgensteins innsikt på det filosofiske studiet av religion. ${ }^{17}$ I møte med beskyldninger om å beskrive ulike religiøse språkpraksiser som semantisk og pragmatisk isolert fra hverandre responderte Phillips med følgende bemerkning:

Religion has something to say about aspects of human existence which are quite intelligible without reference to religion: birth, death, joy, misery, despair, hope, fortune and misfortune[...] Consider Jesus's words, 'Not as the world giveth give I unto you '[...] One could not understand the sense in which Jesus gives unless one also understands the sense in which the world gives. So far from it being true that religious beliefs can be thought of as isolated language-games, cut off from all other forms of life, the fact is that religious belief cannot be understood at all unless their relation to other forms of life is taken into account. ${ }^{18}$

16. Gregersen (2008), 298, 308. Sml. Gregersen (1990), 128f, 34.

17. Til dette og følgende se D. Z. Phillips, Philosophy's Cool Place (Ithaca, N.Y.: Cornell University Press, 1999), 49ff, 87, og D. Z. Phillips, "Locating Philosophy's Cool Place - a Reply to Stephen Mulhall," i D.Z. Phillips' Contemplative Philosophy of Religion, red. Andy F. Sanders (Aldershot: Ashgate, 2007), 51.

18. D. Z. Phillips, Faith and Philosophical Enquiry (London,: Routledge \& K. Paul, 1970), 97. Jf. D. Z. Phillips, Wittgenstein and Religion (New York, N.Y.: St. Mar- 
Phillips ber oss her bite merke $\mathrm{i}$ at innholdet i kristne ord og uttrykk (kristne semantikker) ikke er mulig å beskrive uten å ta hensyn til liknende og/eller kontrasterende ord og uttrykk som ikke faller inn under kategorien "kristne semantikker". ${ }^{19}$ Studiet av "kristendommens store betydningsuniverser" kan derfor ikke bety at det kun er kristne semantikker/pragmatikker som gjøres til tema i samtidsteologi av første orden. For å kunne optimalisere en eksplikasjon av kristne semantikker/pragmatikker må disse relateres til så mange relaterte semantikker/pragmatikker som mulig (både kristne og ikke-kristne, religiøse og ikke-religiøse). Allerede teologi av første orden der ekspliserende dogmatisk arbeid inngår må derfor være komparativ i sitt metodiske arbeid.

Men er det ikke slik at vi først må identifisere og individualisere de størrelser som skal sammenliknes og relateres, for så å eksplisere disse komparativt og relasjonelt? I et essensialistisk rammeverk for systematisk teologi ville en slik prosedyre være naturlig, men dersom pragmatiske, semantiske og ontologiske forhold primart er å bestemme som relasjoner (evt. konfigurasjoner, strukturer), så fortoner eksplikasjonsarbeidet seg ganske annerledes. ${ }^{20} \mathrm{Da}$ handler systematisk teologisk virksomhet om primært å eksplisere relasjonene som sådan. De pragmatiske, semantiske og ontologiske forhold som inngår som tema for teologisk virksomhet, er dermed fullt bestemt først når alle relasjoner er eksplisert. Igjen: eksplikasjon som metodisk prosedyre bør dermed ikke kun begrense seg til teologi av første orden slik Gregersen antyder, men bør inngå i så vel teologi av første, andre og tredje orden.

I praksis innebærer imidlertid dette arbeidet alltid en rekke begrensninger for den enkelte teologiske forsker eller det enkelte teologiske forskningsprosjekt. Men selv om en rekke pragmatiske faktorer begrenser synsvidden for dogmatikkens eksplikative arbeid, driver det teoretiske kravet om optimal presisjon dogmatikere til alltid å utvide synsvidden samtidens diskursive univers. Økt presisjon henger nemlig sammen med å belyse forholdet mellom flest mulig språklige uttrykk. Gregersen uttrykker dette poenget ved å si at dogmatikken liksom filosofien "[...] tematiserer, hvad man bredt kan kalde univer-

tin's Press, 1993), 69. D. Z. Phillips, Belief, Change, and Forms of Life (Atlantic Highlands, NJ: Humanities Press International, 1986), 8f., og Phillips (1970), 99f, 230.

19. I sin artikkel "How to Cope with Pluralism in Dogmatics" neglisjerer Gregersen den ene dimensjonen av familielikhetsbegrepet til Wittgenstein i det han skriver: "As a matter of fact, there exists a continual, non-hierarchical interpenetration between different cultural systems, each following their own codes of evaluation and interest." (Gregersen (1990), 125. Kursivering i original). Familielikhet består ikke bare i å være relatert i kraft av forskjeller, men også i kraft av likheter!

20. Puntel and White (2010), passim. 
selle sammenhænge [..., om det sande og usande [...]". ${ }^{21}$ Tematiseringen av tilværelsens universelle sammenhenger vekker spørsmålet om hvorvidt dogmatikk kan bidra til å utvikle en systematisk teologisk metafysikk. La meg forsøke å videreutvikle Gregersens ansatser til teologi 2 og 3 i så henseende.

\section{Dogmatikk som metafysikk}

Et livssyn, både i religiøse og ikke-religiøse varianter, kan forstås som en måte å forholde seg til tilværelsen som helhet. I kristen tradisjon har dette historisk sett særlig kommet til uttrykk i og gjennom vektleggingen av dens universalistiske karakter. Bibelfortellingen har tradisjonelt blitt forstått som en universalfortelling, i den forstand at den er en fortelling hvis dramaturgi inkluderer, og angår, kosmos som sådan og som helhet. Men selv om andre religioner som islam, hinduisme og buddhisme også uttrykker helhetssyn på tilværelsen, har ikke dette resultert i utviklingen av teoretisk virksomhet slik målet ble det for klassisk kristen systematisk teologi. I kristen tradisjon ble systematisk teologiske presentasjoner forstått som refleksivt etablerte teologiske helhetspresentasjoner av virkeligheten, hvor alle teologiske forhold som angår den menneskelige tilværelse skulle tas med i betraktning. Slik sett forstod de seg selv som de klassiske akademiske fagenes "dronning". I motsetning til hva tilfellet har vært for andre religioners vedkommende, har utviklingen av kristen systematisk teologi som universitetsfag betydd at den kristne religion i særlig grad har forsøkt å stå i et dialogforhold til andre vitenskapsorienterte kulturområder. Problematiseringen av metafysikkens helhetstenkning opp gjennom moderniteten og postmoderniteten impliserte derfor også en kritikk av teologiens status som vitenskapsfag, og ble dermed opplevd som en sterk utfordring for en kristen teologisk virksomhet som ønsket å fremstå som intellektuelt redelig.

En av de postmoderne (evt. postmetafysiske) hovedkritikkene mot klassisk teologisk metafysikk er at den anvender generaliserende strategier som hindrer oss i å få øye på partikulariteten, perspektiviteten, kontekstualiteten, subjektiviteten (osv.) i enhver teologisk bestemmelse av virkeligheten. ${ }^{22}$ Den gir skinn av å presentere universelt gyldige sannheter uavhengig av de subjektive og kulturelle perspektiv

\section{Gregersen (2008), 294.}

22. D. Z. Phillips, "Can There Be a Marriage between Religion and Metaphysics?," in Religion and the End of Metaphysics, red. D. Z. Phillips, Ruhr, M. van der (Tübingen: Mohr Siebeck, 2008), 1. D. Z. Phillips, "Lindbeck's Audience," Modern Theology 4, no. 2 (1988): 136, 42. D. Z. Phillips, Wittgenstein and Religion, 115. 
gjennom hvilke den er artikulert. Kan vi med rette opprettholde et syn på systematisk teologi som en disiplin med universalistiske pretensjoner?

For å kunne besvare dette spørsmålet, må jeg først presisere et bestemt forhold. Selv om et helhetsblikk ofte har blitt ansett for å være konstituerende for systematisk dogmatisk teologi, er det viktig å understreke at systematisk teologi ofte har blitt forstått som å ha et begrenset siktemål, nemlig å presentere den indre sammenheng $\mathrm{i}$ en bestemt teologisk læretradisjon med det formål å gjøre den optimalt forståelig og velbegrunnet (jf. Gregersens beskrivelse av teologi av annen orden). Slik sett har ikke teologisk metafysikk vært en teologisk "teori om alle ting", men snarere en teoretisk rekonstruksjon av teologiske saksforhold slik de kommer til uttrykk i religiøse skrifter som f. eks. Bibelen, ulike bekjennelsesskrifter, Koranen (etc.). Metafysisk tenkning i streng forstand har imidlertid et videre synsfelt enn dette nemlig "alle ting". Fra dette perspektivet vil en systematisk teologi, strengt tatt, kun være metafysisk dersom den fremstår som en livssynsteori der ulike systematiske religionsteologier, samt andre ikkereligiøse helhetssyn, inngår i materialet som danner grunnlaget for en rekonstruksjon av virkeligheten som helhet coram deo. Et slikt prosjekt vil selvsagt være ekstremt komplekst, og i praksis ugjennomførbart for én enkelt forsker. Som tidligere nevnt vil man i praksis måtte begrense seg til å arbeide teoretisk med et bestemt utvalg av dette datamaterialet. Dette utelukker imidlertid ikke at tenkning må være universalistisk orientert slik metafysisk tenkning legger opp til. Tvert imot, jeg mener at all teoretisk virksomhet med nødvendighet må være metafysisk orientert - dog i en helt bestemt forstand. Hva betyr dette for konkret systematisk teologisk virksomhet?

Før jeg presenterer argumenter for hvorfor dogmatikk (forstått som en "tredimensjonal" systematisk teologi àla Gregersen) må være metafysisk, vil jeg henlede oppmerksomheten på presiseringen som ligger $\mathrm{i}$ at den må være slik orientert. I angivelsen av at dogmatikk må være metafysisk orientert, ligger det nemlig bestemte begrensninger. ${ }^{23}$ For det første innebærer det en realitetsorientering, dvs. at kompleksitetsgraden i en slik virksomhet er så høy at hver enkelt teologisk

Jf. Merold Westphal, Overcoming onto-Theology: Toward a Postmodern Christian Faith, første utg., Perspectives in Continental Philosophy (New York: Fordham University Press, 2001), 290-96.

23. Lorenz B. Puntel, "Kann es gelingen, innerhalb eines Systems aus Raum und Zeit zu einer Gesamtschau der Dinge zu gelangen?," in Kann es gelingen,iInnerhalb eines Systems aus Raum und Zeit zu einer Gesamtschau der Dinge zu gelangen?, ed. Thomas Busse, Raumzeit-Zeitraum (Neubrandenburg: Rethra-verlag, 2005), $341 f$. 
presentasjon må begrense seg til å framstille relativt sett grovkornede teologiske bestemmelser av virkeligheten. Metafysikk må derfor, som Aristoteles allerede påpekte, med nødvendighet begrense seg til generelle beskrivelser. ${ }^{24}$ Teologisk å bestemme hver enkelte bestanddel av virkeligheten fullt ut, faller utenfor rekkevidden av metafysisk virksomhet. I denne forstand vil enhver metafysisk orientert teologi alltid være ufullstendig.

For det andre er dogmatisk teologi hypotetisk i den forstand at den aldri kan oppnå absolutt sikkerhet om sine standpunkter. Den må derfor alltid være åpen for korreksjon. Den kan aldri forutsette et absolutt sikkert grunnlag som den kan utlede sine læresetninger fra (slik et fundamentistisk orientert rammeverk for dogmatisk arbeid vil kunne tillate). En systematisk teologisk selvforståelse eksempelvis basert på en tese om Bibelens eller bekjennelsesskriftenes ufeilbarlighet, vil ikke kunne være annet enn naiv dogmatisme. En metafysisk teologi kan aldri være absolutt sikker, men er i sitt vesen kontinuerlig selvkorrigerende. ${ }^{25}$ Robert C. Neville formulerer dette poenget mer radikalt: "Good theology hunts up reasons to doubt in order to reinforce its preciously vulnerable ideas." 26 På denne måten er tvilen en integrert del av systematisk teologi.

For det tredje er gyldigheten av en metafysisk dogmatikk alltid bestemt av det teoretiske rammeverk den er utviklet innenfor. ${ }^{27}$ En slik teoriramme inneholder en rekke antakelser om hvilke begrunnelsesmønstre man kan gjøre bruk av, og hvilken språkforståelse (semantikk) man baserer seg på. Innenfor denne teorirammen kan man ikke begrunne gyldigheten av teorirammen som sådan. For å kunne gjøre dette må man utvikle en overordnet teoriramme hvor den første kan begrunnes. Denne prosedyren kan $i$ prinsippet pågå i det uendelige. Man kan alltid etablere større rammer innenfor hvilke gyldigheten av andre rammer kan vurderes. Et eksempel kan være å vurdere ulike helhetsutkast til systematisk teologi innenfor rammene av religionsteologi, og ulike religionsteologier innenfor rammene av en overordnet rammeverk for normativ livssynsteori (som vel tilsvarer det Gregersen kaller teologi av tredje orden).

I så måte ligger det i denne begrensningen også en universaliserende bevegelse. I en angivelse av systematisk teologi som metafysisk orientert ligger det også en positiv bestemmelse, nemlig den at systema-

24. Aristoteles, "Metaphysica," ed. W. D. Ross (1990), 1059 b26, 60 b30. Jf. Puntel (2005), 341.

25. Jf. Robert C. Neville, On the Scope and Truth of Theology: Theology as Symbolic Engagement (New York: T\&T Clark, 2006), ixff.

26. Ibid., $x$.

27. Puntel (2010), 147ff. 
tisk teologi alltid må søke å utvide sitt erfaringsgrunnlag i kontakt med andre vitenskaper. Først og fremst gjelder dette religionsteologi og normativ livssynsteori. Det er selve denne utvekslingen som gjør teoretisk arbeid meningsfullt. Vitenskapelige diskusjoner består nettopp i å utveksle argumenter for hvilken teoriramme som evner å inkludere flest mulig data. En universalistisk orientering er derfor konstitutiv for denne virksomheten som sådan. Dette er endatil en pragmatisk grunn for hvorfor metafysikk er uunnværlig i vitenskapelig arbeid. Systematisk teologi har en av sine viktigste begrunnelser i selve denne dialogiske praksisen. ${ }^{28}$

Det hefter imidlertid en bestemt problematikk med begrunnelsesprosedyrene til ulike helhetssyn på virkeligheten. Kan man ikke alltid spørre etter videre grunner for det som hevdes innenfor en systematisk helhetsfremstilling? Sagt på en annen måte: kan man ikke alltid artikulere nye hvorfor-spørsmål ad infinitum, og dermed hindre en fremstilling i noen gang å bli helhetlig?

Hvorfor-spørsmål handler om alltid å spørre etter videre begrunnelse for et standpunkt. Innenfor en teoriramme der det kreves at man evner å etablere et standpunkt der ingen videre hvorfor-spørsmål er nødvendige (en ubegrunnbar grunn), vil mangelen på et slikt standpunkt være fatalt for muligheten til å utvikle et helhetssyn på tilværelsen. Evner man ikke å etablere en ubegrunnbar grunn må man se seg tvunget til å innse at en slik spørsmålsstrategi ikke leder noensteds hen - heller ikke til Gud. Alternativet er at man etablerer en teoriramme som ikke arbeider ut i fra en slik strategi.

En systematisk fremstilling av den typen jeg har forsøkt å skissere ovenfor, etableres ikke gjennom å stille hvorfor-spørsmål, men ved å stille hvordan-spørsmål: hvordan henger disse bestemte saksforhold sammen?29 Mekanisk å stille hvorfor-spørsmål til alle saksforhold er problematisk fordi det ofte kan være uklart hvilke saksforhold man ønsker å undersøke sammenhengen mellom. Eksempelvis er det teoretisk sett problematisk å spørre etter (kausal-) forholdet mellom verden og en "ukjent X". Stiller man et hvorfor-spørsmål uten å spørre etter sammenhengen mellom bestemte saksforhold, er spørsmålet å

28. Neville (2006), 3. Men det finnes også en rekke andre grunner for dette. L.B. Puntel foreslår tre mulige måter som teoretisk virksomhet kan utvikle et helhetssyn på tilværelsen. For det første kan dette skje ved å diskursivt etablere et tredjepersonsperspektiv. For det andre er menneskets sinn (Geist) koekstensiv med det ubegrensede diskursive univers som er virkelighetens mest opprinnelige dimensjon. For det tredje kan man utvikle et helhetssyn på tilværelsen ved å eksplisere den sammenheng alle andre sammenhenger utfolder seg $i$, nemlig virkelighetsdimensjonen som sådan og som helhet. Puntel (2010), $185 \mathrm{ff}$.

29. Puntel (2010), 61ff, 205f, 13-17. 
betrakte som et kvasi-spørsmål - et spørsmål uten mål og mening. Forutsetningen for at det skal være mulig å avgjøre om et spørsmål er meningsfullt stilt eller ikke, er altså at det teoretiske rammeverket for diskursen er avklart. ${ }^{30}$ Et slikt teoretisk rammeverk vil bl.a. bestemme hvilke saksforhold man kan undersøke sammenhengen mellom, og på hvilken måte dette kan gjøres (m.a.o. hvilke spørsmål som meningsfullt kan stilles når man undersøker forholdet mellom ulike saksforhold). En koherentistisk teoriramme besvarer ikke primært spørsmålet om hvorfor noe er som det er, men hvordan ulike saksforhold forholder seg til hverandre. ${ }^{31}$ Oppgaven for systematisk teologi av tredje orden vil her bestå i å vise hvordan en bestemt gudsforestilling kan gjøre en helhetsfremstilling av virkeligheten mer koherent (evt. mer bestemt). ${ }^{32}$

\section{Oppsummering}

Jeg har i denne artikkelen forsøkt å eksplisere Niels Henrik Gregersens ansatser til et rammeverk for dogmatisk arbeid i kristen teologi. Eksplikasjon handler altså om å presisere relasjoner mellom ulike forhold. I det ovenstående forsøker jeg å utføre dette arbeidet på tre forhold.

For det første med henblikk på forholdet mellom pragmatikk og semantikk, for det andre med henblikk på forholdet mellom eksplikasjon som sådan og koherentistisk begrunnelsesstrategi, og for det tredje ved å bestemme forholdet mellom de tre dimensjonene ved dogmatisk arbeid som Gregersen skisserer i lys av en ansats til systematisk teologi forstått som metafysikk.

Til det første forsøker jeg å vise at Gregersen mangler en distinksjon mellom semantisk og pragmatisk eksplikasjon som er nødvendig for å presisere hva teologisk virksomhet av første orden faktisk dreier seg om. Semantisk eksplikasjon kan både ta form som pragmatisk ek-

30. At hvorfor-spørsmål kun er meningsfulle innenfor en teoriramme, innebærer videre at hvorfor-spørsmål ikke kan stilles om selve den aksepterte teorirammen (om det da ikke etableres en alternativ teoriramme der dette er mulig). En teoriramme som forutsetter at det må stilles hvorfor-spørsmål til alt, samtidig som det sier at det ikke er mulig å stille hvorfor-spørsmål til teorirammen som sådan, vil havne i uløselige problemer.

31. Puntel uttrykker dette poenget pregnant slik: "Wie sich alles verhält, ist Sein. Sein ist, wie sich alles verhält." Puntel (2010), 88.

32. Hvorfor- og hvordan-spørsmål leder oss på ulikt vis til bestemte gudsforestillinger. Dette kommer særlig klart til uttrykk når man som teolog forsøker å klargjøre hvordan Gud forholder seg til verden som skaper v.h.a. disse ulikes spørsmålsstrategiene. Ibid., $254 \mathrm{ff}$. 
splikasjon av det kristne mennesker gjør, og som en ren språkintern semantisk eksplikasjon av hva kristne mennesker sier når de gjør noe. Skal disse formene for eksplikasjon med rette kunne gå under navnet dogmatikk, og ikke religionssosiologi, er det ikke, slik Gregersen hevder, først og fremst førstepersonsperspektivet (brukerperspektivet) teologer bør ta utgangspunkt i. Skal dogmatikk kunne sortere under betegnelsen systematisk teologisk virksomhet, må kristne bytydningsunivers artikuleres fra et tredjepersonsperspektiv.

Mens Gregersen begrenser det eksplikative arbeidet til det han kaller teologi av første orden, forsøker jeg videre å vise at siden eksplikasjon handler om nærmere å bestemme semantiske og pragmatiske relasjoner, så inngår dette også i teologi av andre og tredje orden. Ettersom komparasjon handler om å belyse semantiske og pragmatiske relasjoner innenfor én sammenhengende ontologisk struktur (virkeligheten gitt som uttrykkbar), så inngår dette som et ledd i det eksplikative arbeidet på alle tre nivåer. Komparasjon begrenser seg dermed ikke til teologi av tredje orden, slik Gregersen hevder. Hensynet til ikke-kristne semantikker/pragmatikker må ivaretas innenfor alle tre former for dogmatisk eksplikasjon. Gregersen gir inntrykk av at vi først må individualisere kristne semantikker, og deretter relatere dem til andre semantikker. Jeg mener imidlertid at innholdet $i$ hva kristne semantikker/pragmatikker er, og hva de faktisk uttrykker, bestemmes relasjonelt. Dermed kan vi ikke først forsøke å individualisere dem for så å undersøke relasjonene de står i til andre semantikker/ pragmatikker.

Det er fokuset på denne grunnleggende relasjonalitet som utgjør skjelettet i min kritikk av Gregersens skisse for dogmatikk som samtidsteologi. Hva gjelder det tredje forhold jeg diskuterer i artikkelen, så skal dette primært forstås som et forsøk på å presentere argumenter for hvorfor dogmatikk må ekspliseres innenfor rammeverket av en eksplisert metafysikk. Slik sett er jeg mindre opptatt av å kritisere Gregersens forståelse av hvordan teologi av andre og tredje orden bør utfolde seg, og mer opptatt av å videreutvikle hans ansatser i retning av en velbegrunnet strategi for å eksplisere dogmatisk samtidsteologi som bestanddel i et systematisk teologisk helhetssyn på tilværelsen. Anerkjennelsen av Gregersens beskrivelse av dogmatikk som en virksomhet som handler om å undersøke universelle sammenhenger, kan derfor rettes mot såkalte "postmetafysiske" retninger innenfor teologi og religionsfilosofi. Fordi virkeligheten er å forstå som en uendelig mengde relasjoner som kan ekspliseres, vil motviljen, man ofte møter blant representanter for denne retningen, mot å utvikle teorier som belyser universelle sammenhenger, motvirke deres egen hensikt om å bidra til økt forståelighet av virkelighetens religiøse dimensjon. 